\title{
Chemomicin A, a New Angucyclinone Antibiotic Produced by Nocardia mediterranei subsp. kanglensis 1747-64
}

\author{
Cheng-Hang Sun ${ }^{\#}$, Yue Wang ${ }^{\#}$, Zheng Wang, Jian-Qin Zhou, Wen-Zao Jin, Xue-Fu You, \\ Hong Gao, Li-Xun Zhao, Shu-Yi Si, Xue Li
}

Received: September 8, 2006 / Accepted: March 7, 2007

(C) Japan Antibiotics Research Association

\begin{abstract}
A new angucyclinone antibiotic, chemomicin A was isolated from cultured broth of Nocardia mediterranei subsp. kanglensis 1747-64. Its chemical structure was determined to be $1,2,3,4 \mathrm{a}, 5,6,6 \mathrm{a}, 12 \mathrm{a}, 12 \mathrm{~b}$-nonahydro1,2,3,8,12,12b-hexahydroxy-3-methyl-6a,12a-epoxybenz[a]anthracen-4,7(12H)-dione by a detailed spectroscopic analysis. Chemomicin A had antimicrobial activity against Bacillus subtilis and Enterococcus faecium with MIC values of 10.2 and $20.4 \mu \mathrm{M}$, respectively, and showed cytotoxicity against human colorectal cancer HCT116 cells and human esophageal carcinoma YES-2 cells with $\mathrm{IC}_{50}$ values of 127 and $153 \mu \mathrm{M}$, respectively.
\end{abstract}

Keywords angucyclinone, Nocardia mediterranei subsp. kanglensis 1747-64, chemomicin A, SF2315B, structural elucidation

Nocardia mediterranei subsp. kanglensis 1747-64 [1] (strain 1747-64), an angucyclinones producing strain, was isolated from soil sample collected from Kang-Le Area, Guangdong Province, P. R. China. Two new angucyclinones, kanglemycin C (2) [2] and kanglemycin M (3) [3] (Fig. 1), were found in the cultured broth of the strain. Aromatic protons (H-9, H-10, H-11) in D-ring of most angucyclinones [4], like PD116779 [5], rubiginones [6], EI-1507-1, EI-1507-2 [7] and ochracenomicins A, B and C
[8], showed ABX coupling system in the downfield region $(\delta 7 \sim 8)$ in their ${ }^{1} \mathrm{H}-\mathrm{NMR}$ spectra. Based on the hypothesis that the strain was a talented producer of angucyclinones like rubiginones producing strain [6], a project to use spectroscopic data mentioned above as a probe in HPLCNMR to further screen new angucyclinones from the cultured broth of the strain 1747-64 was carried out. As a result, new members of angucyclinone group designated as chemomicins were early identified by HPLC-NMR. Among them, chemomicin A (1) was further isolated under the guidance of its retention time in HPLC. Structural studies showed 1 was a unique angucyclinone with six hydroxyl groups, a 4-carbonyl group and a 6a,12a-epoxide functional group (Fig. 1). In this paper, we wish to report the fermentation, isolation, physico-chemical properties, structure elucidation and biological activities of $\mathbf{1}$.

A stock culture of the strain 1747-64 was maintained on Gause No. 1 agar slant consisting of $\mathrm{KNO}_{3} 0.1 \%, \mathrm{NaCl}$ $0.05 \%, \mathrm{~K}_{2} \mathrm{HPO}_{4} 0.05 \%, \mathrm{FeSO}_{4} \cdot 7 \mathrm{H}_{2} \mathrm{O} 0.001 \%, \mathrm{MgSO}_{4}$. $7 \mathrm{H}_{2} \mathrm{O} 0.05 \%$, soluble starch (Beijing Qi Te Xin Chemical Co., Ltd., China) $2.0 \%$, and agar $1.5 \%(\mathrm{pH} 7.0)$ at $4{ }^{\circ} \mathrm{C}$. The stock culture was transferred into $250-\mathrm{ml}$ Erlenmeyer flasks containing $50 \mathrm{ml}$ of seed medium consisting of glucose $3.0 \%$, yeast extract (Shanghai Yeast Manufactory, China) $0.5 \%,\left(\mathrm{NH}_{4}\right)_{2} \mathrm{SO}_{4} 0.5 \%$ and $\mathrm{CaCO}_{3} 0.5 \%(\mathrm{pH} \mathrm{6.5)}$. The culture was incubated on a rotary shaker $(220 \mathrm{rpm})$ at $28^{\circ} \mathrm{C}$ for 48 hours. Five milliliters of the seed culture was transferred to $500-\mathrm{ml}$ Erlenmeyer flasks containing $100 \mathrm{ml}$

Z. Wang: Department of Pharmacy, Guilin Medical College, Guilin 541004, P. R. China

X. Li: BioScience College, Capital Normal University, Beijing 100037, P. R. China

\# These two authors have contributed equally to this work.
C.-H. Sun (Corresponding author), Y. Wang, J.-Q. Zhou, W.-Z. Jin, X.-F. You, H. Gao, L.-X. Zhao, S.-Y. Si: Institute of Medicinal Biotechnology, Chinese Academy of Medical Sciences \& Peking Union Medical College, Beijing 100050, P. R. China, E-mail: chenghangsun@hotmail.com 
<smiles>CC1(O)C(=O)C2CCC34OC3(C(=O)c3c(O)cccc3C4O)C2(O)C(O)C1O</smiles>

1<smiles>O=C1c2cccc(O)c2C(=O)c2c1ccc1cc(CO)cc(O)c21</smiles><smiles>CC1=CC(=O)C2C(=O)c3c(O)cccc3C(=O)C2CCC1(C)O</smiles>

2<smiles>CC1=CC(O)C2C(O)(CCC34OC23C(O)c2cccc(O)c2C4=O)C1</smiles>

4

Fig. 1 Structures of chemomicin A (1), kanglemycin C (2), kanglemycin M (3) and SF2315B (4).

of the producing medium consisting of glucose $4.0 \%$, yeast extract $1.0 \%$, peanut meal $0.5 \%$, peptone (Shanghai Donghai Pharmaceutical Manufactory, China) $0.5 \%$ and $\mathrm{CaCO}_{3} 0.1 \%$ (pH 6.5). The fermentation was carried out at $28^{\circ} \mathrm{C}$ for 96 hours on a rotary shaker $(220 \mathrm{rpm})$.

The fermentation broth (25 liters) was adjusted to $\mathrm{pH} 5.0$ with $2 \mathrm{~N} \mathrm{HCl}$ and filtered. The filtrate was extracted with ethyl acetate (25 liters). The extract was concentrated to a small volume under reduced pressure to give a syrup. It was then chromatographed on a column of silica gel (300 ml, Qindao Silica Manufactory, China) and developed with $\mathrm{CHCl}_{3}-\mathrm{MeOH}, 19: 1(\mathrm{v} / \mathrm{v} 1500 \mathrm{ml})$. Thirty fractions (50 $\mathrm{ml}$ per fraction) were collected and $200 \mu \mathrm{l}$ solutions from each fraction were dried in $1.5 \mathrm{ml}$ eppendroff tubes with $\mathrm{N}_{2}$ stream. Then, the resulting residues were dissolved in $50 \mu 1$ methanol for analysis with HPLC on a Zorbax SBC18 column $(9.4 \times 250 \mathrm{~mm}, 5 \mu \mathrm{m}$, Agilent), with $\mathrm{MeOH}$ $\mathrm{H}_{2} \mathrm{O}, 65: 35(\mathrm{v} / \mathrm{v})$ at $1 \mathrm{ml} /$ minute after filtered through $0.22 \mu \mathrm{m}$ membrane. Fractions (No. 21 to 23 ) containing most of 1 were pooled to yield sample $(166 \mathrm{mg})$. The sample $(83 \mathrm{mg} / \mathrm{ml}, 2 \mathrm{ml})$ was further purified by HPLC on a shim-pack PRC-ODS column $(250 \times 20 \mathrm{~mm}$, Shimadzu $)$ with $\mathrm{MeOH}-\mathrm{H}_{2} \mathrm{O}, 55: 45(\mathrm{v} / \mathrm{v})$ at $4 \mathrm{ml} /$ minute to yield $40 \mathrm{mg}$ of 1 as white powder.

The physico-chemical properties of $\mathbf{1}$ are summarized in Table 1. The molecular formula of $\mathbf{1}$ was established as $\mathrm{C}_{19} \mathrm{H}_{20} \mathrm{O}_{9}$, on the basis of high-resolution SI-MS, NMR spectra in $\mathrm{CD}_{3} \mathrm{OD}$ (I) and in DMSO- $d_{6}$ (II). The ${ }^{1} \mathrm{H}-\mathrm{NMR}$ and ${ }^{13} \mathrm{C}$-NMR spectral data of $\mathbf{1}$ are shown in Table 2.

Analysis of ${ }^{1} \mathrm{H}-\mathrm{NMR}$ and ${ }^{13} \mathrm{C}$-NMR together with DEPT and a heteronuclear single quantum coherence (HSQC) indicated 19 carbon signals of $\mathbf{1}$ could be attributed to two carbonyl carbons, six aromatic carbons (including three methine groups, two quaternary carbons, one oxygensubstituted quaternary carbon), seven other oxygensubstituted carbon signals (including three oxygenated methine groups and four oxygenated quaternary carbons), one methine group, two methylene groups, one methyl group. Six hydroxyl protons at $\delta 11.4$ (H-bonded phenolic hydroxyl proton), 7.1, 6.9, 6.5, 5.4, and 5.1 appeared in ${ }^{1} \mathrm{H}-$ NMR spectrum in DMSO- $d_{6}$, but disappeared in $\mathrm{CD}_{3} \mathrm{OD}$.

Epoxide functional group existed in $\mathbf{1}$ was early deduced from calculating the oxygen atom number and the number of oxygen-substituted carbon signals, since only six oxygen atoms have to be assigned to seven oxygen-substituted carbon signals except that three oxygen atoms were ascribed to two carbonyl groups and one phenolic hydroxyl group.

The IR spectrum indicated the presence of hydroxyl groups $\left(3410 \mathrm{~cm}^{-1}\right)$, a ketone carbonyl group $\left(1714 \mathrm{~cm}^{-1}\right)$ and a chelated carbonyl group $\left(1653 \mathrm{~cm}^{-1}\right)$, which were further confirmed by a ketone carbonyl carbon signal at $\delta$ 204.02 (C-4) and a chelated carbonyl carbon signal at $\delta$ 201.20 (C-7) in ${ }^{13} \mathrm{C}-\mathrm{NMR}$ spectrum in DMSO- $d_{6}$, the same 
Table 1 Physico-chemical properties of $\mathbf{1}$

\begin{tabular}{ll}
\hline Appearance & White powder \\
Molecular weight & 392 \\
Molecular formula & $\mathrm{C}_{19} \mathrm{H}_{20} \mathrm{O}_{9}$ \\
HRSI-MS (m/z) Found: & $391.1033(\mathrm{M}-\mathrm{H})^{-}$ \\
\multicolumn{1}{c}{ Calcd: } & 391.1034 \\
UV $\lambda_{\max }^{\mathrm{MeOH}} \mathrm{nm}(\varepsilon)$ & $217(19,282), 260(8,991), 335(4,564)$ \\
IR $v_{\max }(\mathrm{KBr}) \mathrm{cm}^{-1}$ & $3410,1714,1653,1616,1456,1250,1053$ \\
Solubility & $\mathrm{MeOH}, \mathrm{DMSO}, \mathrm{CHCl}_{3}$ \\
TLC, Rf value & 0.24 \\
HPLC, Rt (min) & 17.6 \\
\hline
\end{tabular}

a Silica gel $60 \mathrm{~F} 254$ (Merck), $\mathrm{CHCl}_{3}-\mathrm{MeOH}, 19: 1$ (v/v).

${ }^{\mathrm{b}}$ Zorbax SB-C18 $(9.4 \times 250 \mathrm{~mm}, 5 \mu \mathrm{m}$, Agilent), $65 \% \mathrm{MeOH}, 1 \mathrm{ml} /$ minute, $254 \mathrm{~nm}$.

Table 2 NMR data of $\mathbf{1}$ in $\mathrm{CD}_{3} \mathrm{OD}(\mathrm{I})$ and in DMSO- $d_{6}$ (II)

\begin{tabular}{|c|c|c|c|c|}
\hline \multirow{2}{*}{ Position } & \multicolumn{2}{|r|}{ I } & \multicolumn{2}{|r|}{ II } \\
\hline & $\delta_{\mathrm{C}}{ }^{a}$ & $\delta_{\mathrm{H}}{ }^{\mathrm{b}}($ mult, $J \mathrm{~Hz})$ & $\delta_{\mathrm{C}}{ }^{a}$ & $\delta_{\mathrm{H}}{ }^{\mathrm{b}}(\mathrm{mult}, \mathrm{J} \mathrm{Hz})$ \\
\hline 1 & 66.52 & 4.5 (br s) & 64.52 & 4.5 (br s) \\
\hline $1-\mathrm{OH}$ & & & & $6.9(\mathrm{br} \mathrm{s})^{\mathrm{c}}$ \\
\hline 2 & 64.77 & $3.5(d, 2)$ & 62.45 & $3.5(d, 2.5)$ \\
\hline $2-\mathrm{OH}$ & & & & $5.1(s)^{c}$ \\
\hline 3 & 60.55 & & 58.65 & \\
\hline $3-\mathrm{OH}$ & & & & $7.1(\mathrm{br} \mathrm{s})^{\mathrm{c}}$ \\
\hline $3-\mathrm{CH}_{3}$ & 15.16 & $1.4(\mathrm{~s})$ & 15.29 & $1.3(\mathrm{~s})$ \\
\hline 4 & 205.15 & & 204.02 & \\
\hline $4 a$ & 50.75 & $2.7(\mathrm{dd}, 12,3.5)$ & 49.16 & $2.7(\mathrm{dd}, 12,3.5)$ \\
\hline \multirow[t]{2}{*}{5} & 16.37 & $\alpha 1.8(\mathrm{~m})$ & 14.89 & $\alpha 1.7(\mathrm{~m})$ \\
\hline & & $\beta 2.1(\mathrm{~m})$ & & $\beta 1.9(\mathrm{~m})$ \\
\hline \multirow[t]{2}{*}{6} & 26.87 & $\alpha 1.9\left(\mathrm{ddd}, 14.5, \sim 14.5^{d}, 4.5\right)$ & 25.33 & $\alpha 1.8\left(\mathrm{ddd}, 14.0, \sim 14.0^{d}, 4.0\right)$ \\
\hline & & $\beta 2.1(\mathrm{~m})$ & & $\beta 2.0(\mathrm{~m})$ \\
\hline $6 a$ & 78.74 & & 77.22 & \\
\hline 7 & 202.22 & & 201.20 & \\
\hline $7 a$ & 114.81 & & 113.42 & \\
\hline 8 & 162.25 & & 160.16 & \\
\hline $8-\mathrm{OH}$ & & & & $11.4(\mathrm{~s})$ \\
\hline 9 & 116.53 & $6.8(d, 8)$ & 115.15 & $6.8(d, 8)$ \\
\hline 10 & 137.45 & $7.5(\mathrm{dd}, 8,8)$ & 136.37 & $7.6(\mathrm{dd}, 8,8)$ \\
\hline 11 & 121.48 & $7.2(d, 8)$ & 120.09 & $7.2(d, 8)$ \\
\hline $11 a$ & 145.31 & & 144.76 & \\
\hline 12 & 65.97 & 5.5 (s) & 64.37 & $5.4(s)$ \\
\hline $12-\mathrm{OH}$ & & & & 5.4 (s) \\
\hline $12 a$ & 76.32 & & 75.60 & \\
\hline $12 b$ & 80.07 & & 78.41 & \\
\hline 12b-OH & & & & 6.5 (s) \\
\hline
\end{tabular}

${ }^{a}$ The ${ }^{13} \mathrm{C}-\mathrm{NMR}$ was measured at $125 \mathrm{MHz} .{ }^{\mathrm{b}}$ The ${ }^{1} \mathrm{H}-\mathrm{NMR}$ was measured at $500 \mathrm{MHz}$. ${ }^{\mathrm{c}}$ Hydroxyl proton assignment may be interchangeable. ${ }^{\mathrm{d} 3} \mathrm{JHH}_{\mathrm{HH}}$ coupling constant between two vicinal protons: $\mathrm{H} \alpha-5$ and $\mathrm{H} \alpha-6$ was unresolved and was deduced from multiplicity of signal for $\mathrm{H} \alpha-6$, which was similar as triplet doublet. 


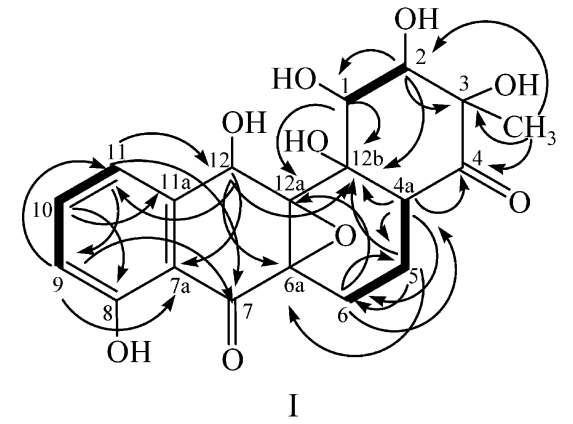

I

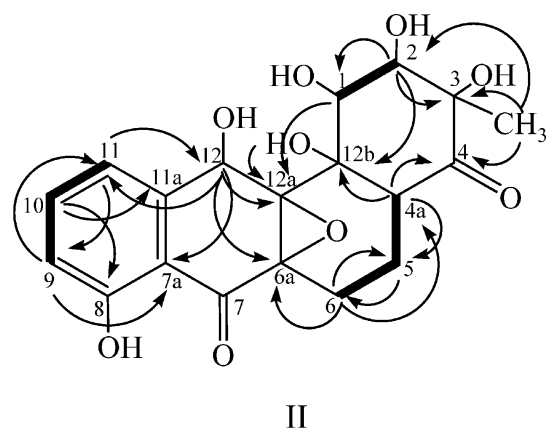

II

\section{$-{ }^{1} \mathrm{H}-{ }^{1} \mathrm{H}$ COSY \\ $\rightarrow \mathrm{HMBC}$}

Fig. 2 Summary of ${ }^{1} \mathrm{H}-{ }^{1} \mathrm{H}$ COSY and $\mathrm{HMBC}$ experiments of $\mathbf{1}$ in $\mathrm{CD}_{3} \mathrm{OD}$ (I) and in DMSO-d $($ (II).

carbon signals could be observed at $\delta 205.15$ and $\delta 202.22$ in $\mathrm{CD}_{3} \mathrm{OD}$. An $\mathrm{ABX}$ coupling system of three aromatic proton signals (H-9 to H-11), the probe mentioned above, was readily observed in ${ }^{1} \mathrm{H}-\mathrm{NMR}$. By tracing the cross peaks from $\mathrm{H}-9, \mathrm{H}-10$ and $\mathrm{H}-11$ in HMBC in DMSO- $d_{6}$ and in $\mathrm{CD}_{3} \mathrm{OD}$, as shown in Fig. 2, C-7a, C-8, C-11a, and $\mathrm{C}-12$ were assigned. The chemical shifts of $\mathrm{C}-8$ at 160.16 in $\mathrm{DMSO}-d_{6}$ and at 162.25 in $\mathrm{CD}_{3} \mathrm{OD}$ suggested that phenolic hydroxyl proton at $\delta 11.4$ in ${ }^{1} \mathrm{H}-\mathrm{NMR}$ (DMSO- $d_{6}$ ) should be attached to $\mathrm{C}-8$, the peri position of the chelated carbonyl carbon (C-7). It was further supported by HMBC $\left(\mathrm{CD}_{3} \mathrm{OD}\right)$, in which, both $9-\mathrm{H}$ and $11-\mathrm{H}$ were long-range correlated with $\mathrm{C}-7$. The chemical shifts of $\mathrm{C}-12$ and $\mathrm{H}-12$ together with the data mentioned above indicated the chromophore of $\mathbf{1}$ is an isosclerone moiety, the same with SF2315B (4) [9], as shown in Fig. 1, which has no absorption peak at wavelength longer than $400 \mathrm{~nm}$, usually shown by quinone chromophore [10]. Hydroxyl proton at $\delta$ $5.68(12-\mathrm{OH})$ of 4 suggested one of two protons at $\delta 5.4$ of 1 should attributed to hydroxyl proton $(12-\mathrm{OH})$.

$\mathrm{H}-12$ was correlated with C-12a and C-6a in HMBC (DMSO- $d_{6}$ ) and cross peak between $\mathrm{H}-12$ and C-6a could be observed as well in HMBC $\left(\mathrm{CD}_{3} \mathrm{OD}\right)$. Thus, C-6a and $\mathrm{C}-12 \mathrm{a}$ were assigned. Considering their chemical shift and the reason oxygen atoms were unproportionate with oxygen-substituted carbon signals, as mentioned above, C$6 \mathrm{a}$ and $\mathrm{C}-12 \mathrm{a}$ should form an epoxide functional group. The substructure (rings C and D) of $\mathbf{1}$ was established as shown in Fig. 1 and was further supported by NMR data comparison between $\mathbf{1}$ and $\mathbf{4}$ and unambiguous elucidation of another substructure (rings A and B) of $\mathbf{1}$.

In another substructure, the two structural fragments: ${ }^{6} \mathrm{CH}_{2}-{ }^{5} \mathrm{CH}_{2}-{ }^{4 \mathrm{a}} \mathrm{CH}$ and ${ }^{12 \mathrm{~b}} \mathrm{C}(\mathrm{OH})-{ }^{1} \mathrm{CH}(\mathrm{OH})-{ }^{2} \mathrm{CH}(\mathrm{OH})$ $\left(\mathrm{CH}_{3}\right){ }^{3} \mathrm{C}(\mathrm{OH})-{ }^{4} \mathrm{C}(\mathrm{O})$ were readily identified by ${ }^{1} \mathrm{H}-{ }^{1} \mathrm{H}$
COSY and HMBC. Linkage between the two fragments was established by HMBC. The methine proton at $\delta 2.7$ (H-4a) was coupled to ketone carbonyl carbon at $\delta 204.02$ (C-4) and oxygenated quaternary carbon at $\delta 78.41$ (C$12 \mathrm{~b})$ in HMBC (DMSO- $d_{6}$ ), meanwhile, methylene proton at $\delta 2.1(5-\mathrm{H})$ and methine proton at $\delta 4.5(1-\mathrm{H})$ were long range coupled to $\mathrm{C}-12 \mathrm{~b}$ in $\mathrm{HMBC}\left(\mathrm{CD}_{3} \mathrm{OD}\right)$. The data above revealed the linkage of two structural fragments through C-4a with C-4 and C-12b.

Long range couplings observed between $\mathrm{H}-12$ and $\mathrm{C}-12 \mathrm{~b}$; between $\mathrm{H}-6$ and $\mathrm{C}-12 \mathrm{a}$; between $\mathrm{H}-5$ and C-6a in $\mathrm{HMBC}\left(\mathrm{CD}_{3} \mathrm{OD}\right)$ fused two substructures through $\mathrm{C6}-$ $\mathrm{C} 6 \mathrm{a}$ and $\mathrm{C} 12 \mathrm{a}-\mathrm{C} 12 \mathrm{~b}$, which were further supported by cross peaks between $\mathrm{H}-1$ and $\mathrm{C}-12 \mathrm{a}$; between $\mathrm{H}-6$ and C-6a in HMBC (DMSO- $d_{6}$ ) as complementary evidence. Hydroxyl proton at $\delta 6.5$ was assigned to $12 \mathrm{~b}-\mathrm{OH}$ by tracing cross peak from C-12a observed in HMBC (DMSO- $d_{6}$ ). Finally, the planar structure of $\mathbf{1}$ was established as $1,2,3,4 \mathrm{a}, 5,6,6 \mathrm{a}, 12 \mathrm{a}, 12 \mathrm{~b}$-nonahydro- $1,2,3,8,12,12 \mathrm{~b}$ hexahydroxy-3-methyl-6a,12a-epoxybenz[a]anthracen4,7(12H)-dione.

In the ${ }^{1} \mathrm{H}-\mathrm{NMR}\left(\mathrm{CD}_{3} \mathrm{OD}\right.$ and DMSO- $\left.d_{6}\right)$ of 1 , coupling constants ( 2 and $2.5 \mathrm{~Hz}$ ) between $\mathrm{H}-1$ and $\mathrm{H}-2$ showed the vicinal protons were cis configuration. Two coupling constants $(12$ and $3.5 \mathrm{~Hz}$ ) between $\mathrm{H}-4 \mathrm{a}$ and $\mathrm{H}-5 \alpha$; H-4a and $\mathrm{H}-5 \beta$ revealed that $\mathrm{H}-4 \mathrm{a}$ and $\mathrm{H}-5 \alpha$ were axial protons in trans configuration and $\mathrm{H}-5 \beta$ was an equatorial proton. The large ${ }^{3} J_{\mathrm{HH}}$ coupling constant $\left(\sim 14.5 \mathrm{~Hz}\right.$ in $\mathrm{CD}_{3} \mathrm{OD}$ and $14.0 \mathrm{~Hz}$ in DMSO- $d_{6}$ ) between two vicinal protons: $\mathrm{H} \alpha-5$ and $\mathrm{H} \alpha-6$ indicated anti-periplanar conformation of these protons and chair conformation of the B-ring [11]. In NOE experiments, irradiation of $\mathrm{H}-2$ enhanced obviously the intensity of $\mathrm{H}-1$ and $3-\mathrm{CH}_{3}$, suggesting that $\mathrm{H}-2$ and $3-\mathrm{CH}_{3}$ should be cis configuration (data not shown). The relative 
configuration of 1 remained to be studied in detail.

Within our knowledge, angucyclinones, including 4, EI-1507-1 and EI-1507-2, rubiginone I, angucyclinone D and elmycin $\mathrm{C}$ [4], possess a 6a,12a-epoxide functional group. Most of them were weakly active against Grampositive and Gram-negative bacteria. For example, EI-1507-1 had weak antimicrobial activities against Enterococcus faecium, Bacillus subtilis and Proteus vulgaris with $\mathrm{MIC}$ values of 120,60 and $60 \mu \mathrm{M}$, respectively. On the other hand, all of them have different bioactivities. For example, 4 showed inhibitory activity against reverse transcriptase of avian myeloblastosis virus [12], and both EI-1507-1 and EI-1507-2 inhibited mature interleukin- $1 \beta$ secretion from THP-1 cell with $\mathrm{IC}_{50}$ values of 1.1 and $1.4 \mu \mathrm{M}$, respectively. Preliminary bioactive studies demonstrated $\mathbf{1}$ had moderate antimicrobial activities against $B$. subtilis and E. faecium with MIC values of 10.2 and $20.4 \mu \mathrm{M}$, respectively, and showed cytotoxicity against human colorectal cancer HCT116 cells and human esophageal carcinoma YES-2 cells with $\mathrm{IC}_{50}$ values of 127 and $153 \mu \mathrm{M}$, respectively. Further studies on detailed biological activities of $\mathbf{1}$ are in progress.

Acknowledgments This work was supported in part by Social Commonwealth Research Project (Project No. 2005DIB1J090), Mega-projects of Science Research for the 10th Five-Year Plan (Project No. 2004AA2Z3784) and National Basic Research Program of China (973, Project No.2004CB518908) funded by The Ministry of Science and Technology of the People's Republic of China. The authors are grateful to Drs. Bin Xin, Wenyi He, Yan Wu, and Jinhua Ni for MS, NMR and IR data. Highly appreciated to Prof. Hiroshi Tomoda in Kitasato University for his valuable scientific discussion and inspiring

\section{References}

1. Li Q, Yao ZY, Yao NT, Li YY. Taxonomic study on the kanglemycin producing microorganism, Nocardia mediterranei kanglesis 1747-64. Chin J Antibiot 20:
246-248 (1995)

2. Wang NJ, Yang XS, He CH. The structural elucidation of kanglemycin C. Chin J Antibiot 19: 86-90 (1994)

3. Sun $\mathrm{CH}$, Wang $\mathrm{NJ}$, Han BL. Isolation and structure determination of kanglemycin $\mathrm{M}$, a new benz[a]anthraquinone antibiotic. Chin J Antibiot 21: 81-83 (1996)

4. Rohr J, Thiericke R. Angucycline group antibiotics. Nat Prod Rep 9: 103-137 (1992)

5. Kern DL, Schaumberg JP, Hokanson GC, French JC. PD 116,779, a new antitumor antibiotic of the benz[a]anthraquinone class. J Antibiot 39: 469-470 (1986)

6. Puder C, Zeeck A, Beil W. New biologically active rubiginones from Streptomyces sp. J Antibiot 53: 329-336 (2000)

7. Tsukuda E, Tanaka T, Ochiai K, Kondo H, Yoshida M, Agatsuma T, Saitoh Y, Teshiba S, Matsuda Y. EI-1507-1 and -2 , novel interleukin-1 beta converting enzyme inhibitors produced by Streptomyces sp. E-1507. J Antibiot 49: 333-339 (1996)

8. Igarashi M, Sasao C, Yoshida A, Naganawa H, Hamada M, Takeuchi T. Ochracenomicins A, B and C, new benz[a]anthraquinone antibiotics from Amicolatopsis sp. J Antibiot 48: 335-337 (1995)

9. Sasaki T, Gomi S, Sezaki M, Takeuchi Y, Kodama Y, Kawamura K. New antibiotics SF2315A and B produced by an Excellospora sp. II. The structural elucidation. J Antibiot 41: 843-848 (1988)

10. Hayakawa Y, Ha SC, Kim YJ, Furihata K, Seto H. Studies on the isotetracenone antibiotics. IV. Hatomarubigins A, B, $\mathrm{C}$ and $\mathrm{D}$, new isotetracenone antibiotics effective against multidrug-resistant tumor cells. J Antibiot 44: 1179-1186 (1991)

11. Bringmann G, Lang G, Maksimenka K, Hamm A, Gulder TA, Dieter A, Bull AT, Stach JE, Kocher N, Muller WE, Fiedler HP. Gephyromycin, the first bridged angucyclinone, from Streptomyces griseus strain NTK 14. Phytochemistry 66: 1366-1373 (2005)

12. Sasaki T, Yoshida J, Itoh M, Gomi S, Shomura T, Sezaki M. New antibiotics SF2315A and B produced by an Excellospora sp. I. Taxonomy of the strain, isolation and characterization of antibiotics. J Antibiot 41: 835-842 (1988) 